\title{
English at Iowa in the Nineteenth Century
}

\author{
JOH N C. GERBER
}

Although The University of Iowa opened its doors in 1855, it was 1873 before its faculty included a professor of English and 1900 before there was a formal department of English. This slow emergence of English as a major subject was not a phenomenon peculiar to Iowa. English was a late bloomer in almost all American colleges and universities. Two forces held it back. One was the feeling, promoted especially by the teachers of Latin and Greek, that the English language as well as its literature was too familiar to be proper matter for advanced study. The other force, especially strong in the new midwestern state universities, was the conviction that English was not practical enough for the training of students who wished to be leaders in the workaday world. As a result of such attitudes, those who wanted to see English become an important part of college and university curricula had to demonstrate that it was both intellectually rigorous and socially useful. How this was accomplished can only be summarized here.

From the opening of Harvard in 1636 the teachers of Greek and Latin controlled the teaching of languages in American institutions of higher education. ${ }^{1}$ Their claims for dominance were impressive: they were continuing the historical tradition dating back to medieval times that the function of the university was to discipline and hence to liberate the mind; they were providing necessary training for future doctors, lawyers, and clergymen; and their subject matter was an intellectual challenge not only because of the nature of the classical languages but also because of the way they taught them. For they taught Greek and Latin not as philosophy or cultural history, which could have made them fascinating, but as philology (linguis-

1 For a detailed study of this topic, see Gerald Graff, Professing Literature, An Institutional History (Chicago: University of Chicago Press, 1987), Chapter 2. 
tics), which according to the testimony of their students made the subject insufferably dull. Classes consisted of endless recitations on assigned texts - the form of the words, their meaning, syntax, and etymology. The classicists were convinced that daily drills of this nature disciplined the minds of undergraduates and in some wondrous fashion liberated them. The classicists, moreover, were determined to keep the study of any other language and literature out of the curriculum unless it could be proved to be equally arduous.

The teachers of foreign languages managed to make their studies acceptable only by imitating the teaching methods of the classicists, i.e., by teaching their literatures as philology. Even by the last half of the nineteenth century, the foreign language teachers were still on the defensive, still wincing from such barbs as the classicists' charge that the teaching of French was on a par with instruction in dancing.

The case for English as a rigorous study was even harder to make because no translation was involved. Children learned to speak the language at a very early age, and students in the public schools learned the rudiments of English grammar and memorized some of the outstanding passages in English and American literature. Nevertheless, there were many who believed that an advanced study of English language and literature deserved a place in college and university curricula. In the late 1850 s and early 1860 s certain scholars began arguing that English could be made as difficult to master as Greek if English texts were taught as though they were Greek, Milton as though he were Homer. Three books were especially influential: George Marsh's Lectures on the English Language (1859), which went through twenty printings, and Origin and History of the English Language and of the Early Literature it Embodies (1862) which went through fourteen printings. Bearing more on teaching techniques was Francis A. March's Method of Philological Study of the English Language (1865), eleven printings. March made no attempt to substitute English for Greek and Latin but argued that the study of all three resulted in a better understanding of each. Although the basic teaching method he 
recommended was the usual philological one, recitations on linguistic minutiae, he did add writing assignments resting on questions without simple, certain answers. He was one of the first, therefore, to couple composition with the teaching of literature. March was tremendously influential, and was probably more responsible than any other one person for getting English into college curricula. March may also have been the first professor of English in the country. In 1857 Lafayette College appointed him (the title is revealing) Professor of English and Comparative Philology. ${ }^{2}$

If English as philology eventually demonstrated that the teaching of English could be rigorous, it was English as public speaking that demonstrated that it could be practical. During the nineteenth century English included rhetoric and such of its practical applications as oratory, declamation, elocution, and debate. Success in such activities, most Americans would have agreed, was one of the keys-maybe the major key - to success in public affairs. The McGuffey readers that were so very popular in the elementary schools, it should be remembered, were meant to inculcate the principles of elocution. The selections were to be read aloud with appropriate voice and body effects, not to be studied for their literary qualities. In college the main purpose of the literary societies was to provide experience in oratory and debate, and the senior declamations let those graduating show off their command of large moral and social issues. In short, even in a new state such as Iowa it was generally agreed that excellence in public speaking was a very useful accomplishment indeed. And, by extension, English in this more inclusive sense came to be viewed as a practical subject. William Riley Parker was eminently correct, therefore, when he wrote that if the father of English was philology, its mother was oratory. ${ }^{3}$

\footnotetext{
${ }^{2}$ For a discussion of the pioneers in the teaching of English, see Phyllis Franklin, "English Studies: The World of Scholarship in 1883," PMLA 99 (May 1984), 350-370.

${ }^{3}$ "Where Do English Departments Come From?" College English 28 (February 1967), 140.
} 
In summary, when Iowa opened its doors in 1855, English had not yet become a major subject in American colleges and universities. Iowa's first faculty almost perfectly mirrored the national pecking order: a professor of ancient languages, a teacher of modern languages, and no one at all in English. The following account, therefore, should be read not as the story of Iowa's attempt to play catch-up in the teaching of English but as a fairly representative example of what was happening at the time in most American universities, certainly in most of the state universities in the Midwest.

\section{7-1869}

Probably no one had college-level instruction in English language and literature in mind when in 1847 Iowa's First General Assembly authorized a university for the brand new state. What the legislators wanted was an institution that would produce the educational and professional leaders the state so badly needed. During the debate on the University, members of the Assembly asserted that the first function of the institution should be to prepare teachers for the common schools. Thomas H. Benton, Jr., Superintendent of Public Instruction, added that it should prepare doctors and lawyers, and Governor James W. Grimes a few years later argued that it might appropriately become a scientific or polytechnic school. There is no evidence that the newspapers or the general public disagreed with these practical objectives. Little, if anything, was said about training the mind for its own sake, or about cultivating literary taste; practical needs seemed too pressing.

When the university's first board of trustees seemed too slow in appointing a president and a faculty, the legislature took things into its own hands by creating a position for a specialist in teacher-training and by looking for possible faculty in such practical fields as chemistry and biology. Finally stirred into action, the trustees offered the presidency successively to three different persons and were turned down by all of them. Almost in desperation they gave the job to Amos Dean, head of the Albany Law School, even though Dean told them he would not move from New York. And he didn't. In four years he made 
only three or four trips to the Iowa campus. But his appointment was by no means a disaster, for in that short time he assembled a small but capable faculty, devised a balanced and innovative curriculum, and worked with the famous educator Horace Mann in creating a unified system for the state's schools. He never, however, could overcome the incompetence of the trustees or persuade the legislature to provide the funds the university needed.

In organizing the University Dean wisely took into account both the traditional work of universities and the special need in Iowa for practical instruction. He divided the University into three parts, the "university proper," the Normal Department (teacher training), and the Preparatory Department (subfreshman). The University proper he then divided into nine departments, five in the language and philosophical area, four in the sciences. Students could select the field or fields in which they wanted to work, and could earn a B.A., B.Ph., or a B.S. Dean, however, had money enough to staff only the Normal and Preparatory departments and three of the departments in the University proper: Ancient Languages (Greek and Latin), Modern Languages (German and French), and Mathematics. In the second year he added the Rev. J.M. Stone to teach physics. Stone seems also to have taught ten students in a class in intellectual philosophy, which included rhetoric and oratory, subjects that eventually came under the aegis of English.

Ironically, the Normal Department came closer to offering a more substantial program in English than the University proper. Because they were going to have to teach the 3Rs, Normal students had to take courses in English grammar, composition, and literature. The course in literature consisted of reading the selections in McGuffey's first four Eclectic Readers as well as the uplifting pieces in Heman's Reader for Young Ladies. Students read the selections aloud with the proper gestures, and memorized many of them. Preparatory students had to study English grammar.

Possibly the most important training in the handling of the language, however, developed outside of the regular classes. 
At the end of every semester each student was expected to deliver a public oration or a reading of an original composition. Topics for these exercises varied widely, as a few examples will show: "Conquest of Thought," "Eloquence of Logic," "Death," "Pickwick," "Blessings Brighten As They Take Their Flight," and, doubtless by some early feminist, "Meddling and Gossiping among Men."

The curriculum devised by Amos Dean stayed in force only until 1858, when a new board of trustees, appalled by the financial condition of the university, closed down everything but the Normal department for two years. Dean approved of the closing, but when the trustees insisted that he move his permanent residence to Iowa City he resigned.

In 1860 a revision of the curriculum put into effect by Silas Totten, the second president of the University, resulted in slightly more attention to English. Totten, an Episcopalian rector who had taught at Trinity College in Connecticut and William and Mary College in Virginia, was also shrewd enough to adapt the traditional concepts of a university to the realities of a midwestern campus. He retained Dean's basic departmental system but reduced the nine university departments to three in the language and philosophical area and three in the sciences. A modicum of English appeared in the department called Philosophy and Rhetoric that Totten assigned to himself. It included rhetoric and English literature for juniors and exercises in the application of rhetoric and logic for seniors. Since only a small minority of students took Totten's course, it can hardly be said that these subjects made much of an impact on the student body. English grammar continued to be required in the Preparatory Department, and the Normal Department offered a variety of subjects that might be called English or English-related: Elementary Sounds of the Language, Reading in English, Spelling as well as Definitions and Analyses of Words, English Grammar including Analysis and Synthesis [elementary philology], Composition and Criticism.

In 1865 the University was reorganized once more, this time during the presidency of Oliver M. Spencer, who had been a 
Methodist minister before coming to the university. Spencer named the university proper the "Collegiate Department," eliminated the semi-independence of its departments, and changed the school year from two to three terms. Also, he tried to eliminate the Preparatory Department on the grounds that such elementary work did not befit a university, but he immediately reinstated it when the members of his faculty complained that not half of the entering freshmen were capable of college work-hardly a surprising complaint since there were still only eighteen high schools in the state with welldrafted courses of study. Under Spencer the Preparatory and the Normal curricula remained relatively the same, but emphasis shifted toward the sciences in the Collegiate Department when Gustavus Hinrichs was appointed to teach physics and chemistry. To a certain extent Hinrichs was coasting on the post-Civil War enthusiasm for science and its practical applications, but his almost maniacal passion for laboratory teaching -and for advertising his method-soon made his program known throughout the country. Not surprisingly, English during Spencer's administration made only small progress. Elements of English were still ancillary parts of the department headed by the president, this time rather grandly called Moral and Intellectual Philosophy and Belles-Lettres. Spencer included rhetoric in the first term of his program for juniors, and English literature, as found in Charles D. Cleveland's anthology, in the third term of his program for seniors. The nature of Cleveland's anthology makes it clear that the students had to memorize and recite historical and linguistic facts relating not only to major texts but to inconsequential ones as well. Clearly, Spencer's English Literature was a course in English philology.

Outside the classroom during these years, the students continued to exploit their native language orally. The catalogs of the time tell that rhetorical exercises were "associated" with all studies with which they could be appropriately connected; one hour each week was set aside for the purpose. The afternoons of the first and third Wednesdays of each month were devoted to "general" rhetorical exercises in the chapel at 
which time all students were required to be present. Moreover, all students were expected to take part each week in "vocal gymnastics" (elocution) under the eye of the professor of their department. In addition, about half of the students belonged to literary societies whose weekly meetings stressed orations, debates, and the reading of original compositions.

\section{9-1900}

In 1869 a series of changes began that resulted in the recognition of English language and literature as one of the major fields in the university. The president from 1868 to 1870 was Rev. James Black, D.D., a former Presbyterian minister and a professor of Latin and Greek. More significantly for this account, he had been a professor of English literature and history at Washington (now Washington and Jefferson) College in Western Pennsylvania. His short period as president at Iowa coincided with dramatic changes in the University. The Law Department opened in 1868 and the Medical Department in 1870. The trustees closed the Preparatory Department and made the Normal Department a purely professional program in the Collegiate Department. The major departments then became Collegiate, Law, and Medicine, each with its own dean. The Dean of the Collegiate Department was T.S. Parvin, a liberally inclined professor of history who did not share the fears of those teaching the classical and modern foreign languages that English was an easy subject that would rob them of their students.

When the trustees abolished the Preparatory Department they added a fifth year to the Collegiate program for "introductory" work. As a result, students took their first three years in the Collegiate Department, dividing their time equally between letters and science. Then they added two years in either the newly established Department of Literature and the Arts or in one composed of sciences. Such changes, plus the fact that President Black himself had taught English literature, created the most promising situation yet for the establishment of a chair in English language and literature. (A chair was the original term for what is now called a department. It had a 
certain aptness because often there was only one person in the field, certainly only one professor.)

The possibility of creating such a chair first came up at a meeting of the trustees in June 1868, but the minutes of the board indicate nothing more than that the subject was discussed. The discussion must have been fruitful, however, for the catalog for 1868-69 contained the following paragraph:

THE ENGLISH LANGUAGE AND LITERATURE is to receive additional attention; it being the intention to commit it as a chief branch to a single instructor, who will make selections from its classics the text for instructions; giving to the words of the tongue, and their history; to the structure of the sentence and its possible modifications; and to the growth of the literature, an attention similar to that which is required in the study of a foreign language, and making the whole practical by repeated exercises in writing, repeating and speaking. ${ }^{4}$

Note the attempt to placate those who might oppose the introduction of English. They are assured that it will be taught as though it were a foreign language, i.e., rigorously, and rendered practical by repeated practice. In other words, it was to be taught by the accepted philological methods.

The "additional attention" became evident in the appointment of Gilbert L. Pinkham, a senior student in the Collegiate Department, as an assistant and in such new courses as Rhetorical, Poetical, and Logical Forms (one term each). Apparently Pinkham did so well that the next year he was promoted to Instructor in English Language and Literature and History with, of course, a still heavier load. In their report to the Thirteenth General Assembly in 1870, the trustees (called regents after 1870) defended the new provision for instruction in English Language and Literature:

Larger provision has been made for the study of the English Language. What has been done is in anticipation of a drill in the language more commensurate with its claims than is common. There is reason to believe that

${ }^{4}$ University Catalog, 1868-69, p. 34. 


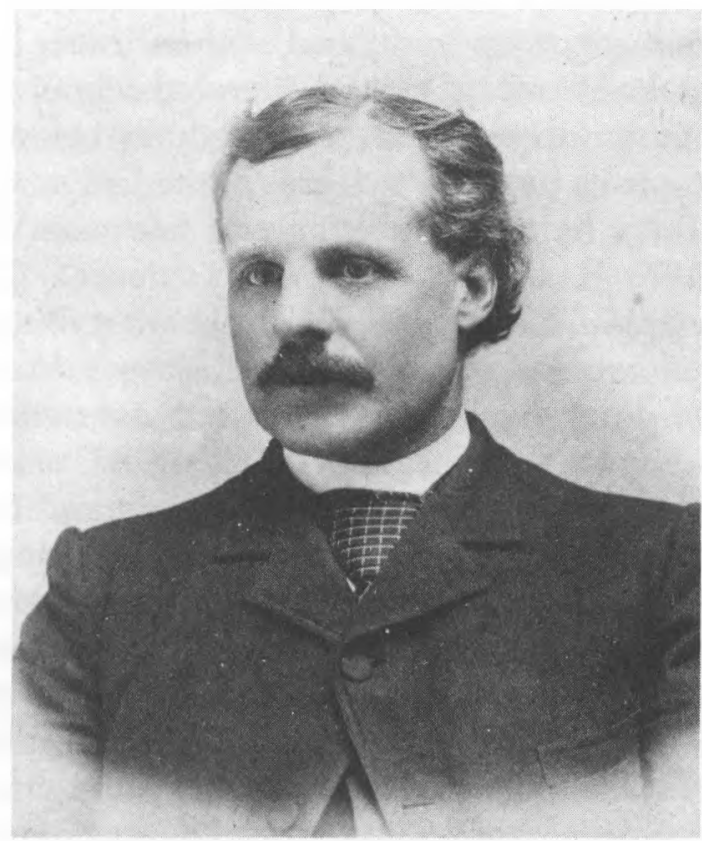

Gilbert L. Pinkham, first instructor of English language and literature.

these claims, even when the language is viewed merely as a means of culture, have been too much overlooked by educators, whereas if the position be taken that the question of training in this or that is to be settled at all times in view of the practical benefit to be derived therefrom, what can exceed in practical importance the organ of one's daily thought whose reaction on the thoughts which it expresses is constant? ${ }^{5}$

Such belabored prose suggests that English was needed not only by the students but by the trustees too. But the point is clear that the study of English had come to be perceived as a study that would both sharpen the mind and be of great practical value. For the most part, Gilbert Pinkham had to

\footnotetext{
${ }^{5}$ Report of the Board of Trustees, Legislative Documents of the Thirteenth General Assembly, 1870, vol. 1, 23.
} 
shoulder the expanded work in English by himself. Fortunately, he was a vigorous and capable man. Born in Village Creek in Allamakee County, he had attended school there and had served as the principal of a private academy before moving to Iowa City to earn a bachelor's degree at the University. After receiving the B.A., he taught full-time for one year. When he took leave in 1870-71 to work on a master's degree, George T. Keller, M.A., taught his classes. On Pinkham's return to the faculty he was relieved of his history classes in order to concentrate on English. Even so, he felt overworked and underpaid, and wrote to the regents in July of 1873 asking them to appoint him to a chair of English Language and Literature because such an appointment had been intimated when he was first hired. Without extended discussion the board members created such a chair and appointed Pinkham to fill it at a salary of $\$ 1600$. At long last, English as a major subject in the University had arrived-though not exactly splendidly.

From 1873 until Pinkham resigned in 1878 the offerings in English to a considerable extent reflected his interests and capabilities. Of course he had to take account of the faculty's insistence that rhetoric (composition) be taught to all the underclassmen and that junior and senior declamations be supervised. But it was undoubtedly due to Pinkham that elective courses appeared from time to time in the history of the language, Anglo-Saxon, Shakespeare, Spenser, Milton, and selected American authors. According to the catalogs, the only assistants he ever had were Caroline H. Pinkham (whether she was a relative is not clear) in 1872-73, Anna C. Bixby in 1874-75, and William Osmond (appointed in both English and German) in 1877-78.

In his annual report to the president, Pinkham frequently complained of his teaching load, but George Thacher, the president from 1871 to 1877 , was too preoccupied with his fight with Gustavus Hinrichs to pay much attention to Pinkham's needs. Under Presidents Spencer and Black, Hinrichs's program in laboratory chemistry and physics had prospered mightily. All students were required to take two years of 
physical science, Hinrichs was awarded two assistants, and the regents had provided funds for North Hall, in which the whole first floor was given over to undergraduate laboratories. Hinrichs had even been sent east to inspect the laboratories in several of the finest universities in order to design the best possible facilities for Iowa. Despite this success-or, maybe because of it-Hinrichs's arrogance made him no friends on the Iowa faculty. So it was that he had no strong supporters when Thacher became president and began to dismantle Hinrichs's program. As a zealot for the classical languages and literatures, Thacher could see little of value in scientific courses. In his reorganization of the curriculum in 1873, Thacher cut the budget in physics and chemistry severely, reduced the requirement from two years to two terms (there were still three terms in the school year), and saw to it that the requirements in the classical and foreign languages and literatures were increased. He then added a second subfreshman year for students without attainments in Latin and German sufficient to meet the admission requirements. Thacher's enthusiasm for languages, however, did not extend to English. The catalog for 1877-78 indicates that in the two subfreshman years students had to take two courses in English, three in German, and eight in Latin. In the four-year scientific program they had to take one course in English (unless one counts courses in rhetoric and elocution), and nine courses in French and German; those in the philosophical program had to take two courses in English and sixteen in some combination of Latin, German, and French; and those in the Classical program had to take two in English, four in German, and fourteen in Latin and Greek. Even in electives English by comparison came off poorly.

The struggle between Thacher and Hinrichs became so violent and so public that the legislature finally felt it necessary to send an investigating committee to Iowa City. Neither man survived very long. Thacher was fired in 1878 for not being able to control his faculty (he was obviously not well), and Hinrichs was fired in the mid-eighties for general obstreperousness. 
Pinkham resigned in June of 1878, giving health and a desire to enter upon other pursuits as his reasons. The University Reporter, the student newspaper, gave overwork as the real reason for his resignation:

We do not wonder at his resignation; for in our opinion [Pinkham] has had more work to do than one man could do, and do well without injury to his health. In addition to his duties as Professor of English Literature and Rhetoric he has had the chair of elocution, which of itself in this University, at least, demands the efforts of one man. We have often sympathized with the Professor when we saw that with his numerous essays to correct and rehearsals to hear, besides his regular duties, he was plainly overtaxed. We would take this opportunity therefore to humbly suggest to the honorable regents that the interests of the University, as well as those of the professor who occupies that chair, demand a division of labor in the professorship which now comprises English Literature, Rhetoric and Elocution. ${ }^{6}$

As early as 1875 the regents determined that the University should have a "lady professor," but it was not until 1878 that their search committee came up with a nominee: Phoebe Sudlow of Davenport, Iowa. Although Sudlow had no academic degrees, she was apparently prepared to teach a number of subjects, and was appointed to the chair of English Language and Literature primarily because it was the first to become vacant. Her salary was set at $\$ 1700$, standard for new professors. The same year, Grinnell awarded her an honorary M.A.

As curious as her appointment in English seems to have been, Sudlow was by no means unequipped for the position. She had collaborated on a book on language and composition, had been principal of the Davenport Training School for Teachers, and in 1877 had served as president of the Iowa State Teachers' Association. With no assistants she single-handedly had to carry the load in English literature, composition, rhetoric, oratory, and elocution. As with Pinkham, her health failed, and in 1881 she was forced to resign. In 1888 she served as

\footnotetext{
${ }^{6}$ Issue of July 1878 , p. 122.
} 


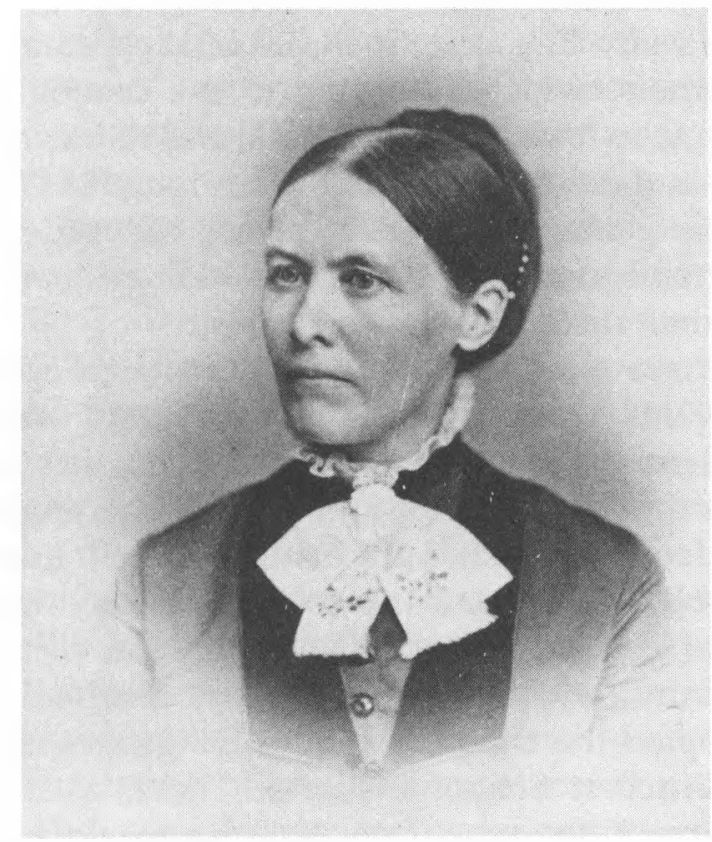

Phoebe W. Sudlow, professor of English language and literature, 1878-1881.

principal of Davenport School No. 1, where she had as a student John G. Bowman, later to be the ninth president of the university.

During Sudlow's tenure, President Christian W. Slagle divided the Collegiate Department into the School of Letters and the School of Science, believing that by formalizing the split between Hinrichs and his foes he might defang them all. (He didn't). English, of course, fell in the School of Letters. Sudlow continued most of the program Pinkham had started, though she gave greater emphasis to composition and dropped American literature altogether. With their stress on narration, description, and argumentation her composition courses anticipated those of a much later date. For sophomores she taught a philologically oriented course that attempted to include nothing less than the origin and growth of the language together with the "lives and literary labor of distinguished English 
authors from the earliest times to the present." For juniors she offered a course in Chaucer, Spenser, Shakespeare, Bacon, Milton, and others, which according to the catalog devoted considerable time to "syntactical analysis, and to tracing words to their origin in the Anglo-Saxon or other tongues." seemed to have gained the respect of her colleagues on the faculty and certainly maintained the work in English at a higher level than did her successor, Susan F. Smith.

It is hard to see why Smith should have been appointed, unless the regents wanted someone who could teach both English and German. She had no academic degrees and was not a specialist in English literature, though she taught composition with dedication. After graduating from St. Louis High School, she took an extended trip to Europe, staying in Italy long enough to learn to speak Italian. Then she visited Switzerland, Germany, and France. When she returned to Missouri, she accepted the chair of Modern Languages and Literature at the Pritchett School Institute. There, as a lady of "generous culture," she taught not only languages but drawing and painting as well. During her years at lowa (1881-1886), for some reason that eludes present historians, she taught as much German as English. As a result the English program suffered, even though the regents relieved her of responsibility for elocution by hiring Edwin H. Booth, M.A., of Chicago as Professor of Rhetoric and Oratory. Aside from composition Smith's work consisted primarily of a fall-term course in eighteenth and nineteenth century writers, a winter-term course in sixteenth and seventeenth century writers, and a spring-term course in Anglo-Saxon and early English. She called her class sessions "recitations" - a tipoff that they were all taught by the philological method. All in all, for English she seems not to have been a fortunate appointment.

When in August of 1887 Smith resigned to get married, the regents declared that they wanted English to be pushed to the fore in the university, and asked their Committee on Faculties

\footnotetext{
${ }^{7}$ University Catalog, 1879-80, p. 21.
} 
and Teaching to find the best literary talent available. The regents' request had the full support of President Charles A. Schaeffer, who was eager to upgrade the university faculty generally. After interviewing "clouds of witnesses" and reading piles of testimonials, the committee recommended Melville B. Anderson for the job. Anderson had studied at Pacific University, Cornell, Göttingen, and Paris, and had earned his Ph.D. at Butler University in Indianapolis. He had taught at Butler, Knox, and Purdue, and was widely known for his translations of French literature, his essays on Sir Francis Bacon, and his scores of reviews in the Dial (Chicago). He was easily the most distinguished person to be appointed to the English faculty during the nineteenth century.

Shortly after he began teaching at Iowa, Anderson argued forcefully in the Vidette-Reporter (September 24, 1887) for the disciplinary value of studying English literature. Suiting his action to his words, he raised the entrance requirements in English to four terms of preparation above the elementary school level and a well-organized composition on a subject drawn from one of a list of English and American classics. He expanded the curriculum to eleven courses, three of which were required of all students. For underclassmen there were four courses in composition, one involving selected orations of Edmund Burke, and another requiring close study of English prose styles based on William Minto's Manual of English Prose Literature, a text made to order for the philological system of memorization and recitation. For upperclassmen there were courses in the history of the language, Anglo-Saxon, Middle English, and American and English literature. A "seminary" for upperclassmen on an epoch in English literature suggests a break with the philological system. In addition, within eight weeks of the beginning of the term every student in the University was to present to Anderson a thousand-word essay or oration.

Although Anderson made it clear before moving to Iowa that he was not interested in teaching elocution, which he called "mouth exercise," he discovered on his arrival that Professor 
Booth, who had been in charge of oratory and elocution, had been "bounced," and that Booth's work had been made part of Anderson's obligations. The regents, however, promised help. For 1887-1888, Marietta Lay was obtained, and for the years afterward, Pauline K. Partridge, a local woman. Partridge's awesome responsibilities in teaching elocution and in reading and listening to orations were alleviated when elocution was taken off the required list and the thousand-word essay or oration was abandoned. Partridge remained on the staff until 1900 at an annual salary of four hundred dollars, a disgraceful figure even for those days. In 1890 the board increased Anderson's salary to $\$ 2000$ but refused to increase Partridge's.

Soon, it was generally agreed that the English program was one of the most popular on campus despite the fact that Anderson refused to provide all the training in elocution that the students wanted. In 1890 he was permitted to add Martin W. Sampson, who had earned an A.B. and an A.M. at the University of Cincinnati and had studied for a year at the University of Munich. Originally appointed an instructor, he was promoted after a year to an assistant professorship, the first person in English to hold that rank. He helped Anderson especially with the language courses.

Anderson remained at Iowa until 1891, when he left to head the relatively new English faculty at Stanford. When he died in 1933 the Daily Iowan printed tributes from such persons as William R. Boyd, Chairman of the Finance Committee of the State Board of Education, and Professors George Patrick (Philosophy) and Benjamin F. Shambaugh (Political Science). They agreed that he was not only a fine scholar but a challenging teacher who would not accept sloppy work from his students. A New York Times editorial praised him particularly for a translation of Dante's Divine Comedy. Anderson was the first of a rather considerable line of distinguished teachers and scholars extending to the present who taught at Iowa relatively early in their careers and then left for wealthier and more prestigious institutions such as Yale, Princeton, and Stanford. 
During 1891-92 Sampson and an acting assistant professor, Nathaniel W. Stephenson, tried to hold Anderson's program together, but at the end of the year both of them left, Stephenson because he had been appointed for only one year and Sampson to take over the English Department at Indiana University. The regents quickly appointed two replacements, Edward Everett Hale, Jr., as professor and Albert E. Egge as instructor. Both men brought Ph.D.'s, Hale from the University of Halle and Egge from Johns Hopkins. More interested in composition than Anderson had been, Hale persuaded the faculty and administration to approve a freshman composition requirement for all students. Conversely, he allowed the work in English and American literature to lose something of the sheen it had acquired during the Anderson years.

Hale provided a brief account of the Iowa program in a little volume entitled English in American Universities, published in 1895. The book contained descriptions of the work in English at twenty of the leading universities. By comparison with Anderson's account of the Stanford program and Sampson's of the one at Indiana, Hale's essay was unimpressive, even apologetic. He maintained that with 250 students registered in English classes and only one professor and one instructor to teach them, the coat had to be cut to the cloth available. Iowa could offer only eight courses, four required and four elective. The required courses were chiefly in rhetoric (composition), and even the basic literature courses were taught with "a rhetorical flavor." The main literature courses were surveys of English poetry and of English prose taught with the help of "Professor Minto's admirable manual."8 It was a pity, Hale concluded, that Iowa could do no more than it did. Obviously Anderson was missed.

\footnotetext{
${ }^{8}$ Edward E. Hale, Jr., "The University of Iowa," English in American Universities (Boston: D.C. Heath, 1895), pp. 83-91. Interestingly, in his brief desciption of the Indiana program, Martin Sampson said that his students were not as willing to study style and develop their latent feeling as were the students he had taught at lowa. (Ibid., p. 97).
} 
When Hale left in 1895 to become Professor of Rhetoric and Logic at Union college in New York, the regents appointed George W. Wauchope, Ph.D., as chair. Wauchope had taught at Washington and Jefferson College, was a specialist in the work of Thomas De Quincy, and continued the emphasis on English prose style and the use of the Minto manual. Because the size of the student body was increasing, Wauchope was able to build the largest English staff yet. To Egge, he added S.E. Irving, M.A., who stayed for one year; Harry E. Kelly, who stayed for three; and George Cram Cook, who stayed for four. By far the most interesting of the group, Cook after leaving Iowa became known as a poet, novelist, and playwright. He experimented with truck-farming, formed the Provincetown Players, and ended up as a shepherd in Greece, where, much acclaimed, he died.

It cannot be said that there was any dramatic expansion in the work for undergraduates during Wauchope's tenure, but the first purely graduate courses appeared in the catalog then, one in Anglo-Saxon and another in Gothic and Old Saxon. Wauchope's chief contribution, however, may have been in establishing the principle that English has three relatively equal obligations: to provide the students with a means of communication, a literature, and a language (composition, literature, and philology). Simple-minded as this may sound, it had considerable merit in that it tended to discourage future staffs from skewing the emphases in the direction of their own interests.

Wauchope left in December 1897 and was followed in January by William P. Reeves, who came with a doctorate from Johns Hopkins and two years teaching experience at Union College. During his tenure the faculty agitated successfully for a change in the basic nomenclature. Iowa was the last major university, they contended, to use the terms "department" and "chair" rather than "college" and "department." In 1900 the regents agreed, and so the "Collegiate Department" became the "College of Liberal Arts" and the "Chair of English Language and Literature" became the "Department of En- 
glish." In 1899 two important additions were made to the staff: Clarke Fisher Ansley was appointed professor, and Sam Berkley Sloan instructor. Both men moved to Iowa from the University of Nebraska, from which they had received their bachelor's degrees. When Reeves resigned in 1900, Ansley became head of the department; he remained in that position until 1917. Ultimately he became editor-in-chief of Columbia University Press and of the Columbia Encyclopedia. Sloan stayed at Iowa until he died in 1967, being remembered as a dramatic teacher and something of a campus "character." He taught a course on the English novel that attracted hundreds of students.

The ties between English and speech instruction, which for years had been weakening, were finally broken when in 1900 the regents appointed Rev. Henry E. Gordon from Amherst as head of a new Department of Public Speaking.

Major changes do not usually coincide neatly with major dates on the calendar. But important events in the history of the English department did cluster around the year 1900. As already indicated, English became a department in that year. The year also marked the beginning of greater stability in staff and curriculum because after 1900 department heads stayed in office longer; from 1900 to 1976 there were only four. With the strong backing of President George MacLean, the department at the turn of the century opened up sufficient graduate courses to allow students to work for graduate degrees. Research became a prime concern of the faculty, and philology began giving way to an emphasis on literary history. In short, the new century brought with it new interests and a new stability in English.

And what of that old nemesis, the Classics faculty? A few figures will show that their influence had not disappeared but that it was slipping. In 1900 Greek had two professors; Latin one professor, one assistant professor and two instructors; English one professor, one assistant professor and four instructors. The catalog announced twelve courses in Greek, twentytwo in Latin, and twenty-four in English. Underclassmen 
electing the Classical program had to take fifteen hours of Greek, twelve of Latin, and twelve of English; those electing one of the two Philosophical programs had to take twelve to twenty-seven of Latin (depending upon whether they substituted French or German in their sophomore year), and twelve of English; and those electing the Science program had to take fifteen hours of Latin unless they substituted a modern language, and twelve of English. Even in the requirements, therefore, English was gaining albeit rather slowly. One thing was certain: those in Classics could no longer hold down the growing demand for English. 